\title{
PENELUSURAN POTENSI MIKROBA ENDOFIT DARI RIMPANG PAKU KEPALA TUPAI (Drynaria quercifolia J.Smith) SEBAGAI PENGHASIL SENYAWA ANTIBIOTIKA
}

\author{
Rusli, Dian Rahmaniar \\ Fakultas Farmasi Universitas Muslim Indonesia \\ Email : ruslimikfarumi@gmail.com
}

\begin{abstract}
This research object to obtain abd determine the activity of antibiotics microbial isolates from endophyticpakukepalatupai (Drynariaquercifolia J. Smith) as a producer of antibiotic compounds. Methods research is using the method in a medium cast nutrient agar and potato dextrose agar with a dilution of $10^{-1}$ to $10^{-5}$. Result showed that there were 5 active isolates on thosetwo medium, identification of isolates bacterial and fungi. Then, the bacteria and fungi isolates purified by quadrant method on nutrient agar and potato dextrose agar medium were in mikroskopic. To produce antibiotic compound fermentation carried out by maltose yeast broth. The results of testing the activity of an antibiotic fermentation with agar diffusion method, results showed that the bacterial active against Bacillus subtilis, Pseudomonas aeruginosa, Streptococcus mutans, Escherichia coli and fungal isolates aktifagains candida albicans. Identification of endophyte microbe isolates carried out by gram staining. Result obtained showed that all isolates of the bacteria were negative Gram and coccus and bacil from.
\end{abstract}

Key word : Antibiotic, Microbial Endophyte, Drynaria quercifolia J. Smith

\section{PENDAHULUAN}

Indonesia adalah negara tropis yang kaya dengan flora dan fauna, banyak jenis tumbuhan merupakan sumber plasma nutfah yang tidak ternilai. Beberapa tahun terakhir ini penggalian sumber daya mikroba yang terdapat di dalam jaringan tanaman mulai banyak mendapat perhatian. Untuk mengambil senyawa bioaktif secara langsung dari tanamannya dibutuhkan sangat banyak biomassa atau bagian dari tanamannya. Untuk mengefisienkan cara memperoleh senyawa bioaktif tersebut, maka digunakan mikroba endofit spesifik yang diperoleh dari bagian dalam tanaman yang diharapkan mampu menghasilkan sejumlah senyawa bioaktif yang dibutuhkan tanpa harus mengekstrak dari tanamannya.

Mikroba endofit adalah organisme hidup yang berukuran mikroskopis (bakteri dan jamur) yang 
hidup di dalam jaringan tanaman (xylem dan phloem), daun, akar, buah, dan batang. Mikroba ini hidup bersimbiosis saling menguntungkan, dalam hal ini mikroba endofitik mendapatkan nutrisi dari hasil metabolisme tanaman dan memproteksi tanaman melawan herbivora, serangga, atau jaringan yang patogen sedangkan tanaman mendapatkan derivat nutrisi dan senyawa aktif yang diperlukan selama hidupnya.

Salah satu jenis tumbuhan yang digunakan dalam pengobatan tradisional adalah tumbuhan paku. Penelitian secara luas mengenai tumbuhan paku yang berkhasiat sebagai obat telah jarang dilakukan. Chopra (1933) dan Kirtikar serta rekan-rekannya (1975) meneliti 44 dan 27 spesies tumbuhan paku secara berturut-turut dan membuat laporan kegunaan tumbuhan pteridophyta dalam hal pengobatan. Kegunaan tumbuhan paku juga dijelaskan oleh Nadkarni (1954) dan Nayar (1959). Mereka melaporkan bahwa 29 spesies tumbuhan paku digunakan dalam sediaan obat. Aktivitas antimikroba dari beberapa tumbuhan paku telah dipelajari (Kumar dan Kausik, 1999; Parihar dan Bohra, 2000 ; 2003) (Kandhasamy, 2008).
Salah satu tumbuhan paku yang berpotensi sebagai obat yakni Drynaria quercifolia J.Smith dikenal dengan nama Paku Kepala Tupai. Tumbuhan ini merupakan salah satu spesies dari suku Polypodiaceae yang banyak manfaatnya. Secara empiris, tumbuhan paku kepala tupai ini digunakan sebagai obat demam tifoid, diare, obat cacing, sakit kepala, dan dipercaya mampu menyembuhkan berbagai jenis luka pada kulit. Keberadaan tumbuhan tersebut di alam terkesan masih kurang mendapat perhatian dari masyarakat.

Berdasarkan hal tersebut maka dilakukan penelitian penelusuran potensi mikroba endofit dari rimpang paku kepala tupai (Drynaria quercifolia J.Smith) sebagai penghasil senyawa antibiotika.

\section{METODE PENELITIAN}

\section{Penyiapan Bahan Penelitian}

Pengambilan sampel

Sampel rimpang paku kepala tupai (Drynaria quercifolia J.Smith) diperoleh dari kawasan UMI (Universitas Muslim Indonesia).

\section{Pengolahan sampel}

Sampel rimpang paku kepala tupai (Drynaria quercifolia J.Smith) dibersihkan dari kotoran-kotoran yang melekat dengan menggunakan air yang mengalir selama 10 menit 
kemudian dipotong-potong kecil. Selanjutnya disterilisasi dengan cara direndam dengan alkohol $70 \%$ selama 1 menit, kemudian dibilas dengan air steril. Sampel dihaluskan dengan cara diblender lalu ditimbang sebanyak 1 gram kemudian dilarutkan dalam $10 \mathrm{ml}$ air steril dan dibuat pengenceran $10^{-1}$ hingga pengenceran $10^{-5}$.

\section{Sterilisasi alat-alat}

Alat-alat yang digunakan dicuci hingga bersih dengan air suling, kemudian alat-alat gelas dikeringkan lalu dibungkus dengan kertas dan disterilkan dengan menggunakan oven pada suhu $180^{\circ} \mathrm{C}$ selama 2 jam. Alatalat gelas yang berskala dan tidak tahan terhadap pemanasan dan yang terbuat dari plastik disterilkan dalam autoklaf pada suhu $121^{\circ} \mathrm{C}$ dengan tekanan 2 atm selama 15 menit. Ose disterilkan dengan cara dipijarkan dengan lampu spiritus.

\section{Penyiapan mikroba uji}

Pembiakan mikroba endofit penghasil antibiotika

Suspensi sampel dari setiap pengenceran dipipet $1 \mathrm{~mL}$ secara aseptis dan dimasukkan ke dalam cawan petri sesuai dengan tingkat pengenceran, lalu dituang sebanyak 9 $\mathrm{ml}$ medium NA dan $9 \mathrm{ml}$ medium PDA pada masing-masing cawan petri, lalu dihomogenkan dengan cara memutar cawan petri membentuk angka delapan. Dibiarkan memadat lalu diinkubasikan selama 1-5 hari pada suhu $37^{\circ} \mathrm{C}$ untuk bakteri dan 1-8 hari pada suhu kamar untuk jamur.

\section{Fermentasi biakan murni}

Koloni biakan murni diambil satu ose, diinokulasikan dalam medium NA miring lalu diinkubasi pada suhu $37^{\circ} \mathrm{C}$ selama $1 \times 24$ jam untuk bakteri dan PDA miring pada suhu kamar selama $3 \times 24$ jam untuk jamur, dan diinokulasikan dalam $10 \mathrm{~mL}$ medium MYB, lalu diinkubasi pada suhu kamar selama $1 \times 24$ jam dan dikocok menggunakan shaker dengan kecepatan 200 rpm.

\section{Penyiapan mikroba uji}

Mikroba uji yang digunakan dalam penelitian ini meliputi bakteri dan jamur. Bakteri yang digunakan adalah Escherichia coli, Bacillus subtilis, Staphylococcus aureus, Salmonella typhi, Pseudomonas aeruginosa, Vibrio cholerae, Streptococcus mutans, Shigella dysenteriae, sedangkan jamur yang digunakan adalah Candida albicans. Stok bakteri dan jamur yang berasal dari stok kultur koleksi Laboratorium Mikrobiologi Farmasi UMI diremajakan 
dalam medium Glukosa Nutrien Agar (GNA) miring dan diinkubasi untuk bakteri pada suhu $37^{\circ} \mathrm{C}$ selama $1 \times 24$ jam dan untuk jamur pada suhu kamar selama $3 \times 24$ jam. Setelah itu dapat digunakan sebagai mikroba uji.

\section{Seleksi dan isolasi biakan}

Setelah diinkubasi dilakukan pengamatan terhadap koloni yang tumbuh yang memperlihatkan adanya zona hambatan berupa daerah bening di sekelilingnya. Koloni ini selanjutnya diisolasi dan dipindahkan pada medium yang sama. Isolasi dilakukan berulang-ulang hingga diperoleh biakan murni yang hanya terdiri dari satu macam koloni. Biakan murni tersebut lalu dipindahkan pada agar miring sebagai stok.

\section{Pengujian aktivitas antimikroba dari isolat mikroba endofit}

Pengujian aktivitas antimikroba yang umum dilakukan ialah cara difusi agar menggunakan medium NA dan PDA.

Disiapkan medium NA dan PDA diambil sebanyak $10 \mathrm{ml}$ dan diinokulasikan $20 \mu \mathrm{L}$ suspensi mikroba uji dan dimasukkan ke dalam cawan petri steril. Biarkan hingga memadat. Disc blanc antibiotic yang telah direndam dalam hasil fermentasi, secara aseptik diatur sedemikian dan diletakkan di atas permukaan medium yang telah memadat. Diinkubasikan pada suhu $37^{\circ} \mathrm{C}$ selama $1 \times 24$ jam untuk bakteri dan suhu kamar selama $3 \times 24$ jam untuk jamur, lalu diamati dan diukur zona hambatan yang terbentuk.

\section{Pengecatan Gram isolat}

Objek gelas dan deck gelas disiapkan yang telah dibersihkan dan dibebas lemakkan dengan alkohol $70 \%$. Dengan ose bulat dibuat film yang tipis pada permukaan objek gelas. Film dikeringkan di udara, kemudian difiksasi dengan cara menyentuhkan permukaan kaca objek gelas pada ujung api bunsen. Setelah didinginkan preparat lalu ditambahkan dengan cat $A$ sebanyak 1-2 tetes, didiamkan selama 1 menit lalu dicuci dengan air mengalir dan dikeringkan dengan tissu. Setelah kering dilakukan perlakuan yang sama seperti pada penambahan cat $A$ secara bergantian mulai dari penambahan cat $B$, cat $C$, dan cat D. Setelah itu, preparat siap untuk diamati di bawah mikroskop. Pengamatan dilakukan dengan melihat bentuk morfologi dan warna isolat mikroba endofit. Warna ungu menunjukkan Gram positif, sedangkan warna merah menunjukkan Gram negatif. 
HASIL PENELITIAN

Isolasi mikroba dari Rimpang Paku

Kepala Tupai (Drynaria quercifolia J.Smith)

Berdasarkan hasil penelitian yang telah dilakukan diperoleh biakan mikroorganisme hasil isolasi dari rimpang paku kepala tupai (Drynaria quercifolia J.Smith) yang menunjukkan 5 isolat bakteri yang diambil pada pengenceran $10^{-1}$ sebanyak satu koloni, $10^{-4}$ tiga koloni dan $10^{-5}$ satu koloni, sedangkan pada jamur diperoleh 5 isolat yang diambil pada pengenceran $10^{-1}$ satu koloni, $10^{-3}$ dua koloni, $10^{-4}$ dua koloni dan $10^{-5} 1$ koloni.

\section{Mikroskopik}

Koloni yang menunjukkan zona hambatan diamati secara mikroskopik untuk melihat bentuk sel dan warna isolat mikroba. Warna ungu menunjukkan bakteri Gram positif, sedangkan warna merah menunjukkan bakteri Gram negatif. Hasil dari mikroskopik dapat dilihat pada tabel 1 .

Tabel 1. Hasil Mikroskopik Isolat Bakteri

\begin{tabular}{ccccc}
\hline \multirow{2}{*}{ No } & Kode Bakteri & Marna & Mikroskopik & \\
\cline { 3 - 5 } & DB1 & Merah & Kokus & Gram Negatif \\
\hline 1 & DB2 & Merah & Kokus & Gram Negatif \\
2 & DB3 & Merah & Kokus & Gram Negatif \\
3 & DB4 & Merah & Kokus & Gram Negatif \\
4 & DB5 & Merah & Batang & Gram Negatif \\
5 & & & & \\
\hline
\end{tabular}

Keterangan :

DB1 : Isolat bakteri ke-1

DB2 : Isolat bakteri ke-2

DB2 : Isolat bakteri ke-3

DB4 : Isolat bakteri ke-4

DB5 : Isolat bakteri ke-5

\section{Pemurnian isolat mikroba}

Koloni mikroba yang telah diperoleh yang menunjukkan zona hambatan lalu digoreskan pada medium Nutrien Agar (NA) untuk koloni bakteri dan koloni jamur digoreskan pada medium Potato Dextrosa Agar (PDA) lalu diinkubasi selama 1 × 24 jam pada suhu $37^{\circ} \mathrm{C}$ untuk bakteri dan 3 × 24 jam pada suhu kamar untuk jamur. Setelah diinkubasi, diperoleh kultur koloni bakteri dan jamur yang murni, kemudian dikulturkan kembali dalam medium Nutrien Agar (NA) dan Potato 
Dextrosa Agar (PDA) miring sebagai stok.

\section{Fermentasi isolat mikroba}

Isolat yang diperoleh kemudian difermentasi dalam medium Maltosa Yeast Broth (MYB) kemudian diinkubasi 1 hari dan dishaker selama $3 \times 24$ jam dengan kecepatan 200 rpm.

\section{Uji aktivitas antibiotika dari isolat mikroba}

Hasil fermentasi yang telah diperoleh diuji aktivitasnya dengan metode difusi agar terhadap Bacillus subtilis, Candida albicans, Escherichia coli, Pseudomonas aeruginosa, Salmonella typhi, Shigella disentri, Staphylococcus aureus, Streptococcus mutans, dan, Vibrio cholerae Hasil fermentasi memperlihatkan zona hambatan, dapat dilihat pada tabel 2 dan 3.

Tabel 2. Hasil Pengukuran Diameter Zona Hambatan dari Isolat Bakteri

\begin{tabular}{|c|c|c|c|c|c|c|c|c|c|c|}
\hline \multirow{2}{*}{ No } & \multirow{2}{*}{ Isolat } & \multirow{2}{*}{$\mathbf{R}$} & \multicolumn{8}{|c|}{ Diameter zona hambatan (mm) } \\
\hline & & & $V C$ & BS & $E C$ & $P A$ & ST & $S D$ & $S A$ & $S M$ \\
\hline \multirow{4}{*}{1} & \multirow{4}{*}{ DB1 } & 1 & 0 & 0 & 0 & 0 & 0 & 0 & 0 & 0 \\
\hline & & 2 & 0 & 0 & 0 & 0 & 0 & 0 & 0 & 0 \\
\hline & & 3 & 0 & 0 & 0 & 0 & 0 & 0 & 0 & 0 \\
\hline & & $\tilde{y}$ & 0 & 0 & 0 & 0 & 0 & 0 & 0 & 0 \\
\hline \multirow{4}{*}{2} & \multirow{4}{*}{ DB2 } & 1 & 0 & 0 & 0 & 0 & 0 & 0 & 0 & 0 \\
\hline & & 2 & 0 & 0 & 0 & 0 & 0 & 0 & 0 & 0 \\
\hline & & 3 & 0 & 0 & 0 & 0 & 0 & 0 & 0 & 0 \\
\hline & & $\tilde{y}$ & 0 & 0 & 0 & 0 & 0 & 0 & 0 & 0 \\
\hline \multirow{4}{*}{3} & \multirow{4}{*}{ DB3 } & 1 & 0 & 10,00 & 18,00 & 16,00 & 0 & 0 & 0 & 21,00 \\
\hline & & 2 & 0 & 10,00 & 17,00 & 18,00 & 0 & 0 & 0 & 20,00 \\
\hline & & 3 & 0 & 10,00 & 18,00 & 17,00 & 0 & 0 & 0 & 20,00 \\
\hline & & $\tilde{y}$ & 0 & 10,00 & 17,66 & 17,00 & 0 & 0 & 0 & 20,33 \\
\hline \multirow{4}{*}{4} & \multirow{4}{*}{ DB4 } & 1 & 0 & 10,00 & 22,00 & 15,00 & 0 & 0 & 0 & 14,00 \\
\hline & & 2 & 0 & 9,00 & 21,00 & 14,00 & 0 & 0 & 0 & 14,00 \\
\hline & & 3 & 0 & 10,00 & 21,00 & 15,00 & 0 & 0 & 0 & 14,00 \\
\hline & & $\tilde{y}$ & 0 & 9,66 & 21,33 & 14,66 & 0 & 0 & 0 & 14,00 \\
\hline \multirow{4}{*}{5} & \multirow{4}{*}{ DB5 } & 1 & 0 & 0 & 0 & 0 & 0 & 0 & 0 & 0 \\
\hline & & 2 & 0 & 0 & 0 & 0 & 0 & 0 & 0 & 0 \\
\hline & & 3 & 0 & 0 & 0 & 0 & 0 & 0 & 0 & 0 \\
\hline & & $\tilde{y}$ & 0 & 0 & 0 & 0 & 0 & 0 & 0 & 0 \\
\hline
\end{tabular}

\section{Keterangan :}

R : Replikasi

y : Rata-rata

DB1 : Isolat bakteri 1

DB2 : Isolat bakteri 2

DB3 : Isolat bakteri 3

DB4 : Isolat bakteri 4

DB5 : Isolat bakteri 5

BS : Bacillus subtilis
EC : Escherichia coli

$P A$ : Pseudomonas aeruginosa

ST : Salmonella typhi

$S D$ : Shigella dysenteriae

$S A$ : Staphylococcus aereus

$S M$ : Streptococcus mutans

VC : Vibrio cholerae 
Tabel 3. Hasil Pengukuran Diameter Zona Hambatan dari Isolat Jamur

\begin{tabular}{|c|c|c|c|}
\hline No & Isolat & $\mathbf{R}$ & $\frac{\text { Diameter zona hambatan (mm) }}{\text { CA }}$ \\
\hline \multirow{4}{*}{1} & \multirow{4}{*}{ DJ1 } & 1 & 15,00 \\
\hline & & 2 & 19,00 \\
\hline & & 3 & 18,00 \\
\hline & & $\tilde{y}$ & 48,00 \\
\hline \multirow{4}{*}{2} & \multirow{4}{*}{ DJ2 } & 1 & 14,00 \\
\hline & & 2 & 14,00 \\
\hline & & 3 & 14,00 \\
\hline & & $\tilde{y}$ & 14,00 \\
\hline \multirow{4}{*}{3} & \multirow{4}{*}{ DJ3 } & 1 & 0 \\
\hline & & 2 & 0 \\
\hline & & 3 & 0 \\
\hline & & $\tilde{y}$ & 0 \\
\hline \multirow{4}{*}{4} & \multirow{4}{*}{ DJ4 } & 1 & 0 \\
\hline & & 2 & 0 \\
\hline & & 3 & 0 \\
\hline & & $\tilde{y}$ & 0 \\
\hline \multirow{4}{*}{5} & \multirow{4}{*}{ DJ5 } & 1 & 0 \\
\hline & & 2 & 0 \\
\hline & & 3 & 0 \\
\hline & & $\tilde{y}$ & 0 \\
\hline
\end{tabular}

Keterangan :

R : Replikasi

ỹ : Rata-rata

DJ1 : Isolat jamur 1

DJ2 : Isolat jamur 2

DJ2 : Isolat jamur 3

DJ4 : Isolat jamur 4

DJ5 : Isolat jamur 5

CA : Candida albicans

\section{PEMBAHASAN}

Penelitian ini dilakukan dengan mengisolasi mikroba endofit yang dapat menghasilkan antibiotika dari rimpang paku kepala tupai (Drynaria quercifolia J.Smith).

$$
\text { Pada penelitian ini }
$$
menggunakan sampel rimpang karena digunakan dalam pengobatan tradisional. Rimpang (dalam botani) adalah modifikasi batang tumbuhan yang tumbuhnya menjalar dibawah permukaan tanah dan dapat menghasilkan tunas dan akar baru dari ruas-ruasnya. Rimpang tumbuhan paku kepala tupai berbeda dengan rimpang yang terdapat dalam tumbuhan tingkat tinggi. Rimpang paku kepala tupai merupakan bagian dari tumbuhan paku kepala tupai yang 
ditutupi oleh sisik yang halus dan lebat berwarna coklat seperti bulu kepala tupai. Secara empiris tumbuhan ini digunakan sebagai obat demam tifoid, diare, obat cacing, sakit kepala, dan dipercaya mampu menyembuhkan berbagai jenis luka pada kulit, Oleh karena itu penelitian pada rimpang paku kepala tupai juga perlu dilakukan untuk mengetahui apakah terdapat mikroba endofit penghasil antibiotika.

Penelitian ini diawali dengan mengisolasi mikroba endofit dari rimpang paku kepala tupai (Drynaria quercifolia J.Smith). Metode isolasi yang digunakan adalah metode tuang, dimana dibuat pengenceran dari $10^{-1}$ sampai $10^{-5}$ untuk meminimalkan jumlah mikroorganisme sehingga memudahkan dalam pengisolasian dan tidak terjadi penumpukan agar lebih mudah dalam pengamatan karena koloni-koloni mikroorganisme yang diisolasi hanya yang memberikan daerah bening disekitarnya, yang membentuk fase stasioner dimana menurut Sermonti pembentukan antibiotika umumnya terjadi pada fase stasioner yaitu mikroorganisme mulai kekurangan nutrisi sehingga mikroorganisme tersebut akan berusaha mempertahankan hidupnya dengan cara menghasilkan metabolit sekunder yang berupa bahan-bahan toksik yang dapat menghambat pertumbuhan mikroorganisme lain. Adapun media yang digunakan untuk mengisolasi mikroba endofit yang terdapat dalam akar rumput tersebut adalah medium Nutrien Agar (NA) untuk bakteri dan Potato Dextrosa Agar (PDA) untuk jamur. Karena kedua medium tersebut mengandung nutrisi yang diperlukan oleh mikroba yaitu ekstrak beef sebagai sumber protein, pepton sebagai sumber asam amino yang terdapat dalam medium Nutrien Agar (NA) dan ekstrak kentang sebagai sumber karbohidrat, dekstrosa sebagai sumber karbon yang terdapat dalam medium Potato Dextrosa Agar (PDA).

Dari proses isolasi di atas diperoleh koloni dengan zona bening diantara koloni- koloni lainnya. Pada medium Nutrien Agar (NA) diperoleh 5 isolat bakteri yang diisolasi dari pengenceran $10^{-1}$ terdapat 1 isolat, $10^{-}$ ${ }^{4}$ terdapat 3 isolat dan $10^{-5}$ terdapat 1 isolat dan pada medium Potato Dextrosa Agar (PDA) juga diperoleh 5 isolat jamur yang diperoleh dari pengenceran $10^{-3}$ terdapat 2 isolat, $10^{-4}$ terdapat 2 isolat dan $10^{-5}$ terdapat 1 isolat.

Hasil isolasi lalu di murnikan dengan metode kuadran sehingga diperoleh kultur koloni mikroba yang 
murni, yaitu isolat yang hanya mengandung satu bentuk morfologi koloni yang sama, dengan metode kuadran yang berpola goresan yang berbeda yaitu dibagi empat, daerah pertama merupakan goresan awal sehingga masih mengandung banyak sel mikroorganisme. Goresan selanjutnya dipotongan atau disilangkan dari goresan pertama sehingga jumlah semakin sedikit dan akhirnya terpisah-pisah menjadi koloni tunggal, sedangkan metode goresan sinambung umumnya digunakan bukan untuk mendapatkan koloni tunggal. Isolat murni tersebut kemudian dibuat menjadi kultur dalam media agar miring sebagai stok.

Setelah memperoleh isolat yang murni, kemudian dilanjutkan dengan fermentasi dalam medium Maltosa Yeast Broth (MYB) selama $1 \times 24$ jam, sambil di shaker dengan kecepatan 200 rpm agar selama fermentasi bakteri akan mencapai fase stasioner dan menghasilkan metabolit sekunder, hal ini sesuai dengan teori yang dikemukakan oleh Salle A.J (1961) bahwa untuk mempertahankan hidup mikroorganisme dapat membuat pertahanan sendiri dengan menghasilkan metabolit sekunder yang mempengaruhi mikroorganime lain sehingga mikroorganisme itu tidak dapat tumbuh dan berkembang biak. Bahan-bahan toksik yang dihasilkan mikroorganisme itu disebut antibiotika. Sehingga untuk melihat potensi dari hasil metabolisme sekunder maka dilakukan pengujian aktivitas antibiotika.

Media fermentasi yang digunakan adalah Maltosa Yeast Broth (MYB), karena media ini merupakan media cair yang megandung ekstrak yeast sebagai sumber protein, maltosa dan dekstrosa sebagai sumber karbon dan pepton sebagai sumber asam amino, yang dibutuhkan dalam pertumbuhan, sintesis sel, keperluan energi dalam metabolisme mikroorganisme.

Hasil fermentasi kemudian dilakukan pengujian aktivitas terhadap mikroba uji. Pengujian aktivitas dilakukan terhadap mikroba uji Staphylococcus aureus penyebab infeksi kulit dan keracunan makanan, Escherichia coli penyebab utama diare kronik, Candida albicans penyebab vaginitis atau keputihan, Pseudomonas aeruginosa yang besifat invasif dan toksigenik dan menimbulkan kebutaan, Vibrio cholerae merupakan bakteri penghasil enterotoksin, Basillus subtilis penyebab bisul, Streptococcus mutans menyebabkan karies pada gigi, 
Salmonella typhi penyebab tifoid dan infeksi saluran kemih, Shigella dysenteriae penyebab disentri. Pemilihan mikroba uji tersebut didasarkan atas sifat-sifatnya yang patogenik yang diharapkan isolat mikroba dari rimpang paku kepala tupai (Drynaria quercifolia J.Smith) dapat menghambat pertumbuhan mikroba patogen tersebut.

Metode yang digunakan dalam pengujian aktivitas antibiotika adalah yaitu metode difusi agar dengan menggunakan disc blank. Metode ini efektif dan efisien. Medium yang digunakan adalah medium NA untuk bakteri dan PDA untuk jamur.

Hasil pengujian aktivitas antibiotika menunjukkan tidak semua isolat mikroba memberikan aktivitas terhadap mikroba uji, yang ditunjukkan dengan tidak adanya zona hambatan yang terbentuk. Adapun isolat yang menunjukkan aktivitas terhadap mikroba uji yaitu isolat bakteri 3 $\left(\mathrm{DB}_{3}\right)$ dan isolat bakteri $4 \quad\left(\mathrm{DB}_{4}\right)$ terhadap Bacillus subtilis, Pseudomonas aeruginosa, Streptococcus mutans, Escherichia coli. Sedangkan untuk jamur, isolat yang menunjukkan adanya aktivitas antibiotoka adalah Isolat jamur $1\left(D_{1}\right)$ dan $2\left(\mathrm{DJ}_{2}\right)$ memberikan aktivitas terhadap Candida albicans Untuk bakteri, diameter zona hambatan yang paling besar adalah isolat bakteri 4 $\left(\mathrm{DB}_{4}\right)$ yaitu $21,33 \mathrm{~mm}$ yang aktif terhadap bakteri Escherichia coli sedangkan pada jamur, diameter zona hambatan yang paling besar adalah isolat jamur $1\left(D J_{1}\right)$ yaitu $48,00 \mathrm{~mm}$ yang aktif terhadap Candida albicans.

Tahap selanjutnya adalah pengecatan Gram isolat bakteri yang bertujuan untuk dapat diklasifikasikan kedalam bakteri Gram positif atau bakteri Gram negatif. Cat-cat yang digunakan dalam pengecatan Gram adalah larutan kristal violet (cat A), larutan iodium (cat B), etanol (cat C), dan larutan safranin (cat D). Cat-cat yang digunakan merupakan senyawa organik yang mengandung gugus kromofor dan gugus ausokrom yang terikat dalam suatu cincin benzen.

Pada tahap pertama digunakan cat $A$ merupakan cat yang bersifat basa, kemudian penambahan cat B akan membentuk kompleks kristal violet-iodium di dalam sel bakteri, penambahan cat $\mathrm{C}$ sebagai dekolorisasi, akan melunturkan zat warna sebelumnya dan cat $D$ untuk memberikan warna kontras pada selsel dan sifatnya tidak menyerap zat warna sebelumnya. Hasil pengecatan Gram yang diperoleh menunjukkan bahwa semua isolat bakteri 
merupakan bakteri gram negatif dan berbentuk kokus dan batang.

\section{KESIMPULAN}

Berdasarkan hasil penelitian yang telah dilakukan maka dapat disimpulkan bahwa :

1. Isolasi mikroba endofit penghasil antibiotika dari rimpang paku kepala tupai (Drynaria quercifolia J.Smith) sebagai penghasil senyawa antibiotika menghasilkan 5 isolat bakteri dan 5 isolat jamur.

2. Isolat bakteri yang diperoleh memberikan aktivitas terhadap Bacillus subtilis, Escerichia coli, Streptococcus mutans,

Pseudomonas aeruginosa, dan Escherichia coli.

3. Isolat jamur yang diperoleh memberikan aktivitas terhadap Candida albicans.

\section{DAFTAR PUSTAKA}

Bibiana W, L. 1994. Analisa Mikroba Di Laboratorium. PT. Raja Grafindo Persada, Jakarta.

Castillo, U.F., G.A. Strobel, E.J.Ford, W.M. Hess,H.P., J.B.Jensen, Heather Albert, Richard Robinson, M.A. Condron, D.B. Teplow, Dennis Steven, and Debbie Yaver. 2002. Munumbicins, wide-spectrum antibiotics produced by Streptomyces NRRL 30562, endophytic on Kennedia nigricans. Microbiology.148. pp.2676.
Djide, M., N. 2005. Analisis Mikrobiologi Farmasi. Fakultas MIPA, Universitas Hasanuddin: Makassar.

Dalimarta,S., 2000. Atlas Tumbuhan Obat Indonesia, jilid 2. Trubus agriwidjaya, Jakarta.

Garrity, G.M., Bell, J. A., and Lilburn, T.G., 2004, Taxonomic Outline of The Prokaryotes Bergey's Manual of Systematic Bacteriologi, $2^{\text {th }}$ Edition, Spiringer, New York Berlin Hendelbergh, United states of America.

Kandhasamy M, Arunachalam K,D, Thatheyus AJ., Drynaria quercifolia (L.) JSM. A potential resource for antibacterial activity. African Journal of Microbiology Research. 2008; 2: 202-205.

Kill, M, A. 1995. Candida a Practical Hand Book For Sufferers. Bloomsburry, Bandung.

Prihatiningtias, W., 2005. Senyawa bioaktif Fungi Endofit Akar kuning (Fibraurea chloroleuca Miers) sebagai senyawa antimikroba. Tesis. Sekolah Pascasarjana UGM.

Radji, M. 2005. Peranan Bioteknologi dan Mikroba Endofit dalam Pengembangan Obat Herbal, Majalah IImu Kefarmasian Fakultas MIPA, Universitas Indonesia, Jakarta.

Strobel G. A., \& B. Daisy. 2003. Bioprospecting for Microbial Endophytes an Their Natural Products. Microbiol. And Mol. Biology. 
Susilowati, D. N., R. Saraswati, E. Yuniarta. 2003. Isolasi dan Seleksi Mikroba Diazotrof Endofitik dan Penghasil Zat PEmacu Tumbuhan pada Tanaman Padi dan Jagung. Balai Penelitian Bioteknologi dan Sumberdaya Genetik Pertanian.

Tarabily, K., A. H. Nassar., K. Sivasithamparam. 2003. Promotion of Plant Growth by An Auxin- Producing Isolate of
The Yeast Williopsis Saturnus Endophytic In Maize Roots. The Sixth U. A. E University Research Conference.

Tanaka, M., Sukiman, $\quad H$., Takebayashi, M., Saito, K., Suto, M., Prana, MS., dan Tomita, F., 1999. Isolation, Screening and Phylogenetic Identification of Endophytes from Plants in Hokaido Japan and Java Indonesia. Microbes and Environment 14(4) 